\title{
Do Learning Activities Improve Students' Ability to Construct Explanatory Models with a Prism Foil Problem? ${ }^{1}$
}

Mihael GoJKošEK ${ }^{\star 2}$, Josip SLIŠKO ${ }^{3}$, and GoraZd Planinšıč ${ }^{4}$

$\approx$ The transfer of knowledge is considered to be a fundamental goal of education; therefore, knowing and understanding the conditions that influence the efficiency of the transfer from learning activity to problem solving play a decisive role in the improvement of science education. In this article, the results of a study of 196 highschool students' ability to transfer knowledge in explanatory model construction are present. Three test groups were formed, traditional, prediction and lab groups, in which students were involved in three different learning activities. A week after instruction, students were tested with a foil test and Lawson's Classroom Test of Scientific Reasoning. According to the results, little knowledge transfer from learning activities to the foil test occurred. Among the three tested learning methods, the one asking for prediction seems to best improve the transfer of knowledge. Time spent on activities had little or no effect on the transfer of knowledge. Some possible reasons for the observed results are presented, and the importance of correct scientific explanation during the learning process is considered.

Keywords: Knowledge transfer; Prism foil problem; Learning activities; Explanatory model; Prediction; laboratory activity

1 Findings of the research were presented on The World Conference on Physics Education in July 2012 in Istanbul, Turkey.

$2{ }^{\star}$ Corresponding Author. Faculty of Mathematics and Physics, University of Ljubljana, Slovenia; gojkosek@fmf.uni-lj.si

3 Facultad de Ciencias Fisico Matematicas, Benemerita Universidad Autonoma de Puebla, Mexico

4 Faculty of Mathematics and Physics, University of Ljubljana, Slovenia 


\section{Ali različne aktivnosti pri učenju lahko izboljšajo sposobnost dijakov pri konstruiranju razlagalnega modela pri problemu prizmatične folije?}

Mihael GojKošEK*, Josip SlišKo In GoRAZd Planinšič

$\propto$ Transfer znanja se pojmuje kot temeljni cilj poučevanja. Za izboljšanje poučevanja naravoslovja je pomembno poznati in razumeti pogoje, ki vplivajo na učinkovitost transferja $\mathrm{z}$ učne aktivnosti na reševanje problema. $\mathrm{V}$ prispevku bomo predstavili izsledke raziskave o sposobnosti transferja znanja 196 srednješolcev pri oblikovanju razlagalnega modela. Oblikovali smo tri testne skupine - tradicionalno, napovedovalno in laboratorijsko, v katerih so dijaki izvajali tri različne učne aktivnosti. En teden po izvedeni učni aktivnosti so dijaki rešili test o prizmatični foliji in Lawsonov test znanstvenega sklepanja (Lawson's Classroom Test of Scientific Reasoning). Izsledki so pokazali, da je bil transfer znanja $\mathrm{z}$ učnih aktivnosti na test o foliji majhen. Med tremi eksperimentalnimi skupinami je bil povečan transfer še največji pri napovedovalni skupini. Trajanje učne aktivnosti je imelo majhen oz. ničen vpliv na transfer znanja. Predstavili bomo nekaj mogočih razlag za pridobljene izsledke in razpravljali o pomenu pravilne znanstvene razlage med učnim procesom.

Ključne besede: transfer znanja, problem prizmatične folije, učne dejavnosti, razlagalni model, napovedovanje, laboratorijska aktivnost 


\section{Introduction}

Knowledge transfer is widely considered to be a fundamental goal of education (Marini \& Genereux, 2004). Usually, this transfer is seen as the ability to apply knowledge and skills to new contexts and problems that differ from the initial learning situation (Barnett \& Ceci, 2002; Eraut, 2004). Constructivist belief, according to which any process of building new knowledge starts with a foundation of everything that is already known by the learner (Michael \& Modell, 2003), emphasises the importance of prior knowledge and, in particular, students' ability to transfer that knowledge into new situations. Considering the similarity between learning activity and the task in which one should apply knowledge, transfers can be near or far (Marini \& Genereux, 2004). Additionally, some knowledge and skills, when acquired, are content specific while other knowledge and skills may be more readily transferred to a new domain (Michael \& Modell, 2003). One of important elements involved in knowledge transfer is instructional context, which also includes instruction and support provided by the teacher (Marini \& Genereux, 2004).

The aim of this study was to compare three instructional practices and their influence on the success of knowledge transfer in the case of a prism foil problem.

The development of effective teaching and learning strategies, which offer potential for improving outcomes of science and physics courses, has been a focus of science education research in recent decades (Meltzer \& Thornton, 2012). One of the first researchers to emphasise the importance of students' active participation in the learning process was Robert Karplus, who (in collaboration with Myron Atkin) presented instructional model of guided discovery (Atkin \& Karplus, 1962). The three phases of Karplus's cycle for science teaching are: Exploration, Concept introduction, and Concept application (Karplus, 1977). A newer approach based on work of Karplus, which extended learning cycle by two phases, is the so-called ${ }_{5} \mathrm{E}$ cycle, consisting of five phases: Engagement, Exploration, Explanation, Elaboration, and Evaluation (Bybee et al., 2006). In physics education research, White and Gunstone (1992) presented activities based on a three-phase cycle known as Predict, Observe, Explain. Two learning cycles were presented by Lillian McDermott in order to help physics students to overcome resistant difficulties. The first cycle consists of phases called Observe, Recognize, Apply, while the second consists of three phases called Elicit, Confront, Resolve (McDermott, 1991). These two cycles are not distinct strategies, but are part of much broader learning approach called Physics by Inquiry (McDermott, 1996). Another active learning educational framework that overcame boundaries of 
basic learning cycles, and includes a number of strategies to involve students in authentic scientific tasks is the Investigative Science Learning Environment (Etkina \& Heuvelen, 2001). Several studies showed that understanding is improved by students' engagement in the learning activity. Crouch, Fagen, Callan and Mazur (2004), for example, found that learning can be enhanced by asking students to predict the outcome of the demonstration before seeing it but after showing the introductory experiment. In this study, we have attempted to upgrade this finding by addressing students' ability to construct explanatory models.

Explanation and the nature of it have played a central role in the history of science. For a long time, studies in philosophy, anthropology and sociology have been focused on how scientists generate and evaluate scientific explanations (Duschl, Schweingruber, \& Shouse, 2007). Since science education is inspired by authentic scientific research, several researchers investigated students' ability to construct explanations for physics phenomena (e.g. McNeill, Lizotte, Krajcik, \& Marx, 2006; Redfors \& Ryder, 2001; Ruiz-Primo, Li, Tsai, \& Schneider, 2010). However, few studies have directly addressed a possible connection between this ability and the nature of prior instruction about the phenomenon. Therefore, we focused our study on effects that learning activities may have on the success of knowledge transfer to physics-phenomenon related problem solving.

\section{Our research question was:}

How do different learning activities influence the transfer of knowledge in the construction of explanatory models for prism foils?

We decided to compare three kinds of instruction: teacher's explanation without students' engagement, teacher's explanation accompanied by a request for a prediction, and independent laboratory activity. Students' ability to construct explanatory models for prism foil has already been investigated (Gojkošek, Planinšič, \& Sliško, 2012), but, without any prior learning activity, the problem seemed to be too demanding for highschool students. We hypothesized that learning activities about the optical properties of rectangular prisms will increase the number of correct explanatory models.

\section{Prism foil}

A prism foil is a thin transparent film that is flat on one side and with microscopic prismatic ridges on the other side; a cross-section is shown in Figure 1. A prism foil is a part of a backlight system in common LCD monitors and can be obtained by disassembling a broken monitor. Its advantage is that one can perform 
similar experiments as with macroscopic prism without revealing its structure. More information about the optical properties of prism foil and its pedagogical applications can be found in the article of Planinšič and Gojkošek (2011).

For the purpose of the research, we used two simple demonstration experiments involving prism foil. When the light beam from a torch is incident perpendicularly to the prism side of the foil, the beam undergoes two refractions and emerges at angles $\pm \alpha$, depending on which side of the prism the beam strikes (Figure 2a). When light is incident perpendicularly to the flat side of the foil, it undergoes double total internal reflection and returns back into the original direction (Figure $2 \mathrm{~b}$ ). The sequence of these two experiments, after which students are encouraged to explain the structure of the foil on the basis of observed results, is called the prism foil problem.

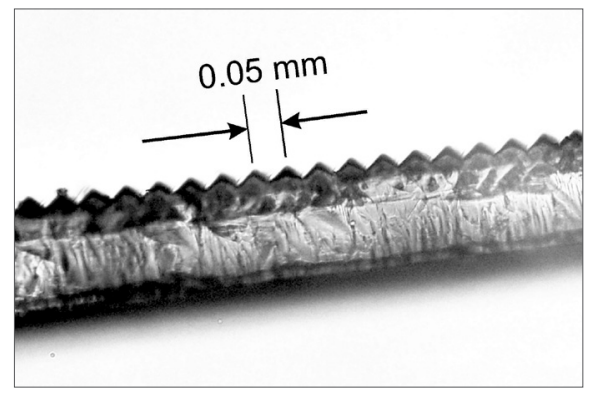

Figure 1. Cross-section of prism foil observed under the laboratory microscope.
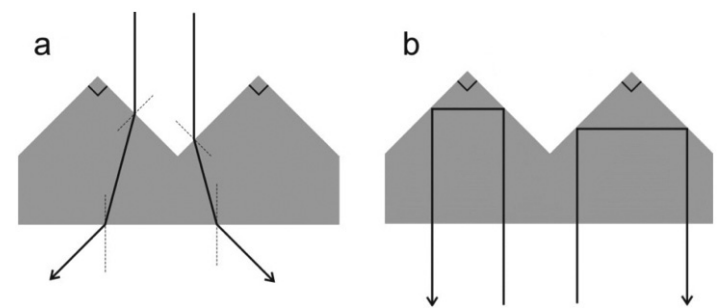

Figure 2. a) Light beam incident perpendicularly to the prism side of the foil undergoes double refraction and emerges at angles $\pm \alpha$. b) Light beam incident perpendicularly to the flat side of the foil undergoes double total internal reflection and returns in the original direction. 


\section{Research design}

A total of 196 students aged between 17 and 19 from three Slovenian secondary schools were included in our research; 113 of them were females and 80 were males. Gender was determined from students' names written on their tests. All three schools were located in urban districts. Physics was a compulsory subject and lessons followed prescribed curriculum. Before they were tested, the students took lessons on reflection, refraction, total internal reflection, image formation, diffraction and interference of light. Our study was implemented in three steps: the first students were involved in the learning activity with the prism that was followed by two tests: the foil test and Lawson's Classroom Test of Scientific Reasoning.

\section{Learning activities}

Students were involved in three kinds of learning activities with a laser ray-box and a three-sided prism made of Plexiglas with isosceles rectangular triangle as a base surface. Three test groups, called the traditional, prediction and lab groups, were formed for the purpose of the research.

In the traditional group, a physics teacher showed students three demonstration experiments. The first experiment showed a double refraction of the laser beam that occurs when light is incident at the angle of 45 degrees to the prism (see Figure 3a). The second experiment showed the internal reflection of the beam when light was incident perpendicularly to one of prism's shorter sides (see Figure $3 \mathrm{~b}$ ). In the third experiment, the teacher presented double total internal reflection when light was incident perpendicularly to the prism's longer side (see Figure $3 \mathrm{c}$ ). The teacher performed the experiments and explained observed results using Snell's law in a qualitative way with minimum engagement of students. The whole activity took about five minutes.

a)

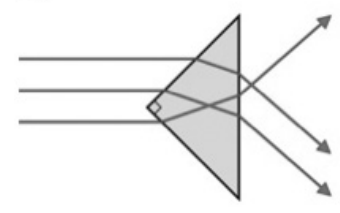

b)

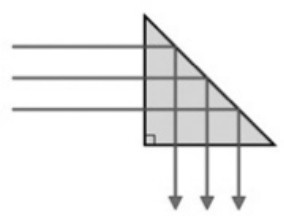

c)

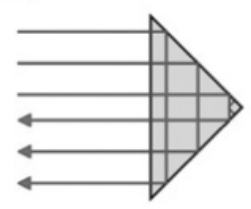

Figure 3. Sketches of demonstration experiments performed with rectangular prism and laser ray-box. 
In the prediction group, the teacher showed students first and second demonstration experiments (double refraction and single total internal reflection) in the same way as previously described. Then he showed the setup of the laser ray-box and the prism for the third experiment and asked students to predict the outcome without showing the experiment. Students illustrated their predictions in their notebooks. After that, the teacher performed the experiment whereupon one of the students was encouraged to explain the observed result aloud and then the whole class discussed it. This activity took between 5 and 10 minutes.

In the lab group, students were divided into groups of 4 or 5 . We gave them written instructions for the laboratory activity, which included sketches of the experimental set ups like those in Figure 4. Their task was to perform each experiment, to draw a ray diagram of the observed result and to explain the result by using the laws of involved optical phenomena. The students wrote their answers in the lab reports. The whole activity took 45 minutes.

a)

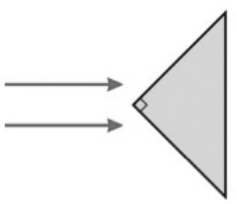

b)

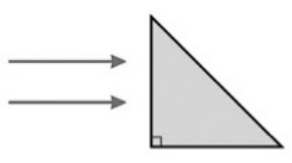

c)

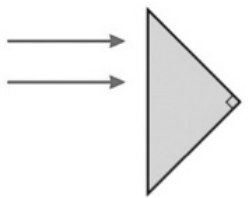

Figure 4. Sketches of experimental setups for laboratory activity in lab test group.

\section{Foil test}

Approximately one week after the learning activities took place students were tested with foil test, which was based on the prism foil problem and was developed by our research group. We assumed that prism foil is an unknown element to students. Instead of the term 'prism foil' we used 'a special foil' in order not to suggest its structure. Part of the foil test consisted of two demonstration experiments in which students observed the split of the light beam when the light was incident perpendicularly to one side of the foil, and the reflection of the beam when it was incident perpendicularly to the other side.

In the first question, we asked the students to sketch and describe the observed outcomes of the experiments. In second question, the students' task was to draw and to verbally describe their explanatory model for the foil's structure. Additionally, they had to name an optical phenomenon that might be the 
reason for the observed results. At the end of the task, they were encouraged to express, on the scale from 1 to 5 , their confidence in the correctness of their explanatory model. In the last question, we asked them if they were surprised by the outcomes of the experiments and, if they were, what surprised them most. It took students approximately 30 minutes to finish the test.

\section{Lawson's Classroom Test of Scientific Reasoning}

As a reference test, we used Lawson's Classroom Test of Scientific Reasoning (CTSR). The test was developed by Anton E. Lawson as an instrument for measurement of formal-level reasoning (Lawson, 1978). The reliability of the test has been confirmed in several studies (e.g. Ates \& Cataloglu, 2007; Coletta \& Phillips, 2005; Lawson et al., 2000). A revised version of the test with 24 multiple-choice questions was translated into the Slovenian language and used in this study.

Questions were combined in 12 pairs of form question-argumentation. Each pair was coded with one point when both answers were correct and with none otherwise; the total number of points was 12. Students who scored between o and 4 points were classified as concrete-logical thinkers, students with scores between 5 and 8 were classified as transitional, and students with 9 points or more were classified as formal-level thinkers. The reliability analysis gave a value of 0.724 for Cronbach's alpha coefficient, which is comparable to results reported by other researchers (e.g. She \& Lee, 2008).

\section{Analysis}

In the analysis of the foil test, we coded the optical element (or physics concept) that was proposed as the basis of foil's structure by students. Similar to our previous research (Gojkošek, Planinšič, \& Sliško, 2012) we formed nine groups named after key elements included in the explanation: prism, lens, diffraction grating, mirror, channel, layer, other, incomplete, and no model.

We also coded the quality or sophistication of explanatory models and their consistency with common physics knowledge on a scale from 1 to 5 .

Models that give no explanations were coded with 1 . Models that merely describe the observed result but do not provide any explanation for the foil's structure or are incomprehensible were coded with 2 . In this group were also classified those explanatory models that include only a sketch without verbal description or verbal description without a sketch of the foil. (Note that students were explicitly asked to use both representations in the explanatory model construction task.) 
We split Code 3 into three subcategories. When a student described the structure of the foil, which by his/her opinion was crucial for observed results, but did not connect this structure with specific optical phenomenon, we coded this with Code 3.1. Code 3.2 was assigned when a student explicitly stated some physics (optical) phenomenon that in his/her opinion played a crucial role for the observed outcomes of the experiments, but the structure of the foil that would employ this phenomenon was not addressed. Code 3.3 was assigned to explanatory models that consist of optical phenomenon and a description of the foil's structure, but these two did not form a consistent whole (e.g. student states non-existent optical phenomenon or uses optical elements and phenomena contradictorily, like 'the lens reflects the light').

Explanatory models that described the structure of the foil and employed corresponding physical concept in the explanation, but contained one or more physics mistakes, or inconsistent use of the concept were coded with 4. Usually in such models the use of physics concept differed from generally accepted physics knowledge in a way that the outcomes matched the observed experimental results. A typical example is diffraction grating that produces interference maxima only in two symmetrical directions (without central reinforcement) or a diverging lens that splits the parallel beam of light into two separate beams.

Models that included descriptions of the foil's structure, employing corresponding physical concept in the explanation in a consistent way, and contained no mistakes were coded with 5. Table 1 includes examples of typical explanatory models proposed by students for every quality code.

\section{Results}

The average score measured by Lawson's Classroom Test of Scientific Reasoning was 7.6 (63.5\%); 30 students (15.3\%) were classified as concrete-logical thinkers; 90 students $(45.9 \%)$ were classified as transitional thinkers and 76 students $(38.8 \%)$ were classified as formal-logical thinkers. These results are similar to reports of students' reasoning levels in other studies (e.g. Ates \& Cataloglu, 2007; Marušić \& Sliško, 2012). The reasoning abilities of students in three test groups were comparable. The average scores of students in the traditional, prediction, and lab groups on CTSR were $7.3(61 \%), 7.6(64 \%)$ and 7.1 (59\%), respectively. The percentages of concrete-logical, transitional, and formal-logical thinkers in each group are presented in Figure 5. Differences in students' scores on CTSR between test groups were analysed using a one-way ANOVA test. The differences have been proven not to be statistically significant 
$(\mathrm{p}=0.544, \mathrm{~F}=0.610)$. However, we found a significant difference between Lawson's scores of males and females ( $70 \%$ vs. $55 \%$, respectively). An unpaired ttest showed that difference is statistically highly significant $(\mathrm{p}<0.001, \mathrm{t}=5.518$, $\mathrm{df}=186.776$ ). Unequal variances of gender groups were assumed in the analysis. No other gender-related analysis has been made.

Only five students out of 196 successfully constructed an entirely correct explanatory model; four of them were tested in the prediction group and one in the lab group. Their average score on CTSR was $82 \%$; four of them were classified as formal-level thinkers, while one was classified as a concrete-level thinker (she scored 33\%). There was also one student in the lab group who constructed a partially correct explanatory model: instead of double total internal reflection, he explained reflection of the light beam on one side of the foil through the total reflection on its flat surface. The total number of explanatory models that involved prism(s) in some way was three in the traditional group, five in the prediction group and three in the lab group.

Table 1. Examples for typical explanatory models proposed by students for quality codes 1-5.

\begin{tabular}{|c|c|c|c|c|}
\hline $\begin{array}{l}\text { quality } \\
\text { code }\end{array}$ & $\begin{array}{l}\text { student's } \\
\text { code }\end{array}$ & student's sketch & $\begin{array}{l}\text { student's verbal } \\
\text { description }\end{array}$ & our notes \\
\hline 1 & AE25 & (no sketch) & (no description) & \\
\hline 2 & AD18 & (1) & $\begin{array}{l}\text { In the first experiment, } \\
\text { the beam of light } \\
\text { goes through the foil } \\
\text { and is split into two } \\
\text { beams (we can see two } \\
\text { circles). } \\
\text { In the second } \\
\text { experiment, the } \\
\text { beam of light cannot } \\
\text { go through the foil; } \\
\text { therefore, it is reflected } \\
\text { into the opposite } \\
\text { direction. }\end{array}$ & $\begin{array}{l}\text { Student AD18 } \\
\text { only described } \\
\text { the observed } \\
\text { result and did } \\
\text { not address the } \\
\text { structure of the foil } \\
\text { or involved optical } \\
\text { phenomena. }\end{array}$ \\
\hline
\end{tabular}




\begin{tabular}{|c|c|c|c|c|}
\hline 3.1 & $\mathrm{AC} 22$ & cross-section of the foil & $\begin{array}{l}\text { The foil consists of } \\
\text { several fibres. Whether } \\
\text { the foil transmits the } \\
\text { light or not depends on } \\
\text { the fibres' layout. }\end{array}$ & $\begin{array}{l}\text { Student AC22 } \\
\text { constructed her } \\
\text { explanation of the } \\
\text { structure of the } \\
\text { foil (fibres), but } \\
\text { did not explain } \\
\text { which optical } \\
\text { phenomenon } \\
\text { affects the beam } \\
\text { of light. }\end{array}$ \\
\hline 3.2 & AD14 & & $\begin{array}{l}\text { When the light beam } \\
\text { is incident on the first } \\
\text { side of the foil, the } \\
\text { rays are bent, and two } \\
\text { beams are formed (due } \\
\text { to different refractive } \\
\text { indexes of air and foil). } \\
\text { When the light beam } \\
\text { is incident on the other } \\
\text { side of the foil, rays are } \\
\text { reflected; the foil works } \\
\text { like a mirror. }\end{array}$ & $\begin{array}{l}\text { Student AD14 built } \\
\text { an explanatory } \\
\text { model on the } \\
\text { optical phenomena } \\
\text { (refraction and } \\
\text { reflection), } \\
\text { but did not } \\
\text { suggest suitable } \\
\text { structure for such } \\
\text { explanation. }\end{array}$ \\
\hline 3.3 & AK16 & mirror & $\begin{array}{l}\text { Light can pass only } \\
\text { through slots; it is } \\
\text { refracted in mirrors and } \\
\text { then falls on the screen } \\
\text { in two beams. } \\
\text { Light is mostly } \\
\text { reflected on the convex } \\
\text { mirror and therefore } \\
\text { no light can be seen on } \\
\text { the other side. }\end{array}$ & $\begin{array}{l}\text { Note that Student } \\
\text { AK16 explicitly } \\
\text { stated construction } \\
\text { elements of the foil } \\
\text { (slots, mirror) and } \\
\text { optical phenomena } \\
\text { involved } \\
\text { (refraction, } \\
\text { reflection), } \\
\text { but their use is } \\
\text { confusing (light } \\
\text { is 'refracted in } \\
\text { mirrors'). }\end{array}$ \\
\hline
\end{tabular}




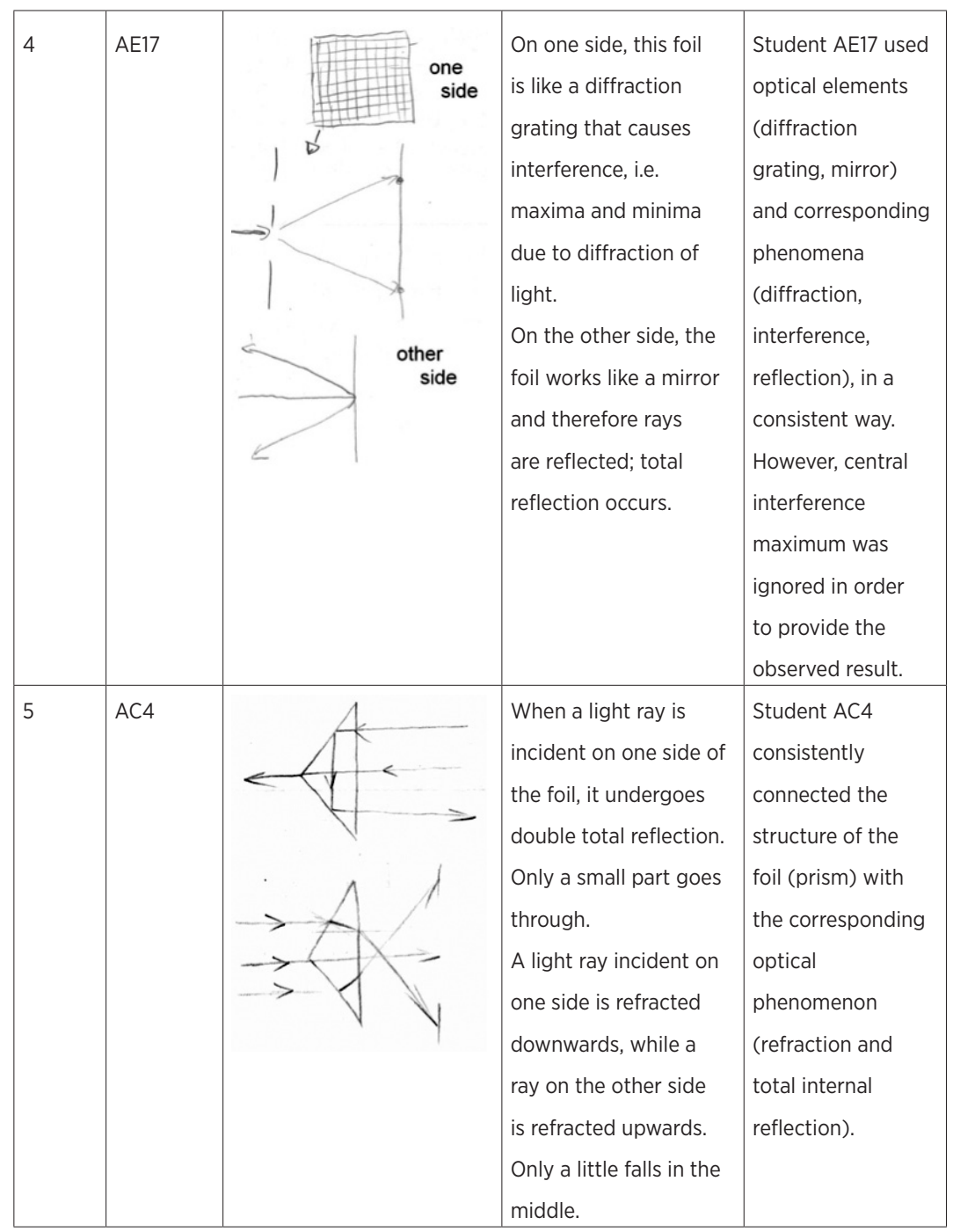

No major difference between the frequencies of quality codes for explanatory models in three test groups was found. Mostly students constructed explanatory models that were coded with Codes 2, 3 (which includes Codes 3.1, 3.2 and 3.3), and 4. Only a few students constructed explanatory models of the highest quality, and also only a few constructed no model at all. Percentages of explanatory models of different qualities in the traditional, prediction and lab groups can be seen in Figure 6. Since the frequency of quality codes in test groups were similar, we combined all results in one group and analysed them. 


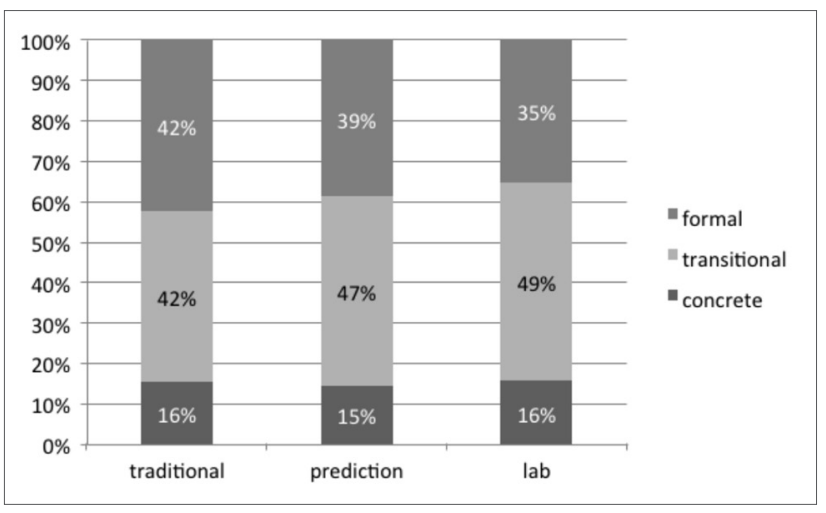

Figure 5. Comparison of students' cognitive abilities in traditional, prediction and lab groups. Percentages of concrete-logical, transitional and formallogical thinkers in each group are very much alike. The difference between groups was shown not to be statistically significant.

We found a strong connection between the quality of explanatory model and the score on Lawson's CTSR. Almost 6o\% of concrete-logical thinkers constructed explanatory models that were coded with quality Code 2, while this percentage drops to approximately $40 \%$ in transitional and less than $15 \%$ in formal-reasoning groups. Quality Code 3, which includes Codes 3.1, 3.2, and 3.3 , was assigned to approximately $25 \%$ of concrete-level thinkers, while these percentages in transitional and formal-level groups are about 45\%. Among quality Codes 3, Code 3.1, which was assigned to explanatory models based on descriptions of the structure, was the most frequent in all reasoning groups. This was followed by Code 3.3, while Code 3.2 (explanatory models based on optical phenomenon) was assigned less frequently. Additionally, we found that no Code 3.2 was assigned in the concrete-level group, while it was assigned to approximately $10 \%$ of explanatory models in other reasoning groups. We found significant increase of explanatory models of Quality Code 4: while there is only $10 \%$ of such models in concrete-level and $15 \%$ in transitional reasoning groups, $35 \%$ of such explanatory models constructed by formal-level thinkers can be found. The results are shown in Figure 7.

\section{Discussion}

Since only five students out of 196 (2.6\%) were able to construct an entirely correct explanatory model, we believe that little transfer of knowledge from the learning activity to the prism foil problem occurred. Comparing the 
results to our previous research (Gojkošek, Planinšič, \& Sliško, 2012), we can see that active learning methods may improve transfer of knowledge, but the complexity of the testing problem still results in a strong floor effect. Several possible reasons for such poor achievements can be considered.

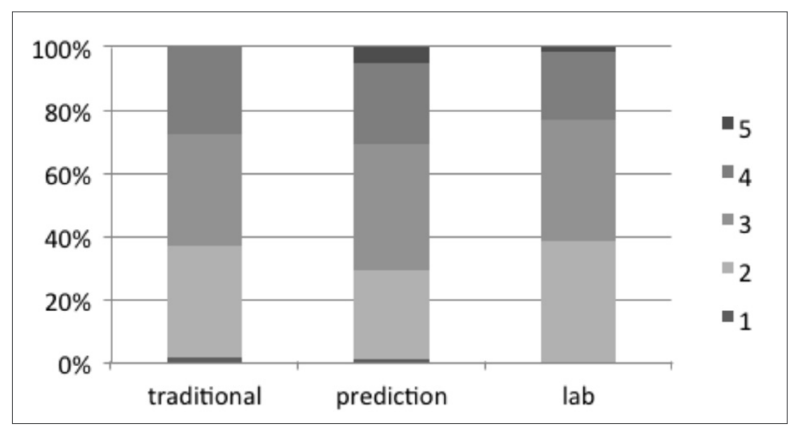

Figure 6. The graph shows the frequency of occurrence of explanatory models coded with quality codes 1-5 in traditional, prediction and lab group.

First, the transfer of knowledge from the learning activity to the prism foil problem is a far transfer. It seems that both problems do not appear similar to students, and probably the most difficult task for them is to transfer knowledge from the macroscopic (prism in the learning activity) to the microscopic scale (prism foil). Another factor that influences the distance of transfer is the time elapsed between the learning activity and the testing problem. We believe that students would be more successful if the foil test would be administrated immediately after the learning activity.

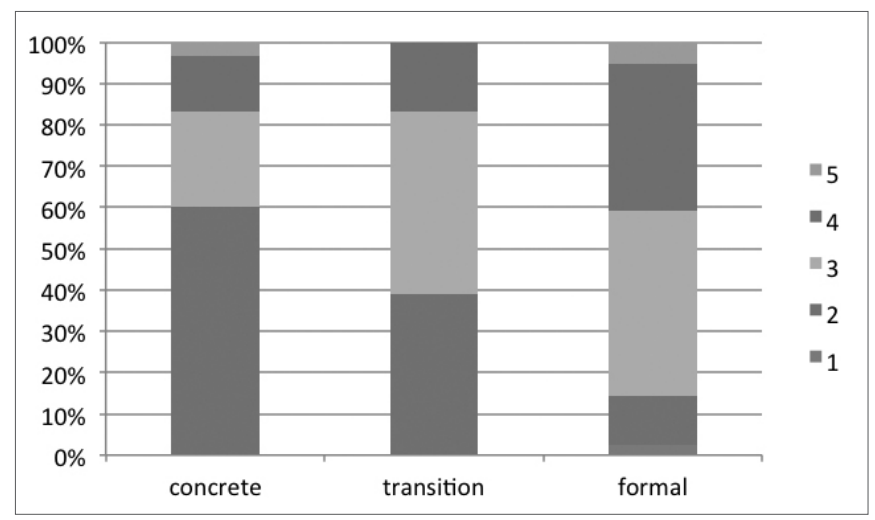

Figure 7. Graph shows occurrence of explanatory models coded with quality codes 1 to 5 in groups of concrete-logical, transitional and formal-logical thinkers according to their scores on CTSR. 
Secondly, the question of what was learned by students in the learning activities should be explicitly addressed. People must achieve a threshold of initial learning that is sufficient to support knowledge transfer (Bransford et al., 2000). We believe that, at least in the traditional group, this criterion was not satisfied. The length of the learning activity and poor engagement of students might have resulted in little (or no) knowledge, which was not sufficient for successful transfer.

Thirdly, the complexity of the prism foil problem may require that the problem be addressed in several steps. In our previous research (Gojkošek, Planinšič, \& Sliško, 2012), two different task sequences were applied during the problem solving. We showed that students were more successful when they observed the surprising result at the beginning, which was followed by observation of a second experiment that provided additional (less or not surprising) data. Breaking a larger problem into smaller sub-problems that are easier to comprehend is an effective strategy in problem solving (Catrambone, 1998; Gick, 1986). In this study, both experiments were presented simultaneously. Consequently, students had to operate with a greater quantity of the information, upon which a consistent explanatory model should be built. Especially for concrete-logical thinkers, this is a challenging task.

Our results suggest that students in the prediction group were the most successful ones (4 entirely correct explanatory models; 5.3\%), followed by the lab group (1 entirely and 1 partially correct explanatory model; $1.8 \%$ ), while students in the traditional group did not construct any correct explanatory models. Moreover, the number of explanatory models that involve prisms in any way suggests that prediction group was the most successful one. Those results provide further support to the belief that learning with students' active engagement in the form of prediction of experimental outcomes provides more knowledge in comparison to traditional methods (Crouch, Fagen, Callan, \& Mazur, 2004). We believe that the students' participation resulted in deeper knowledge, which was observed through more cases of successful knowledge transfer in the prism foil problem solving.

We hypothesized that hands-on laboratory activity might provide even deeper understanding; however, our results do not suggest this. One possible explanation for that may be found in the method of students' investigation. They obtained precise instructions for the laboratory activity, and their task was to explain the observed results, using knowledge of corresponding physics phenomena. However, at the end of their activity, the teacher did not provide them any explanation model that would support (or disprove) their assumptions and explanatory schemes. The authors believe that the lack of teacher's explanation 
may result in less learning, as students' explanations without the support of authority (teacher) remain mere speculations and their understanding of the observed process remains unevaluated and questionable. Our results suggest that lab exploration alone, without any reflection on previous knowledge, may not be enough for meaningful learning and consequently successful transfer of knowledge. These results are in resonance with the findings of other researchers, who reported the greater effectiveness of guided (enhanced) discovery when compared to unassisted (unguided) or minimally guided instructional approaches (Alfieri, Brooks, Aldrich, \& Tenenbaum, 2011; Mayer, 2004).

Another important observation is that time spent on the activity is not the most influential factor for successful transfer. Learning activity in the lab group lasted 45 minutes, while in the prediction group it took less than 15 minutes. Despite the much shorter time spent on the instruction, students from the prediction group seem to be more successful in the transfer of knowledge. On the basis of this result, we conclude that more important than the duration of the learning activity is its nature. In other words: it is more important how we teach students instead of how long we teach them.

The fact that most of the students who constructed correct explanatory models are formal-level thinkers supports the finding from our previous study: formal reasoning skills are a key factor in the construction of explanatory models for prism foil. However, there was one student that managed to find the solution of the problem with concrete-level reasoning skills. This may suggest that asking for predictions during demonstration experiments may help nonformal thinkers to transfer knowledge.

The nature of the instruction methods does not seem to influence the quality of students' explanatory models. This is not a surprising result. Short learning activities may increase knowledge, but have a much smaller impact on the development of competences needed for the construction of sophisticated and consistent explanatory models. In contrast, a connection between quality of models and students' cognitive level was expected. Higher cognitive abilities, such as hypothetico-deductive reasoning, are essential in the construction of complex explanations based on the observation of surprising data.

We believe that frequency of Code 3.2 also indicates differences in students' reasoning abilities. Note that no concrete-logical thinker constructed the model coded with quality Code 3.2. This code was assigned to explanatory models based on knowledge of optical phenomenon involved in the experiment, which, on the other hand, contained no or too little information about the structure of the foil. It would be contradictory if a concrete-level thinker would base his/her explanation on abstract concepts like those composing the 
transferable knowledge of optical phenomenon in question. Such models, however, were found in transitional and formal-level reasoning groups.

\section{Conclusions}

In our study, we investigated the ability of 196 highschool students aged 17 to 19 to transfer knowledge from a learning activity to problem solving with prism foil. Three different instructional methods were used: teacher's demonstration and explanation of observed results without students' engagement was performed in the traditional group. In the prediction group, the teacher showed and explained two experiments, while the third one was performed after the students' prediction of its outcome. In the lab group, students were involved in unguided laboratory activity, in which they performed all three experiments by themselves. Students were later tested with Lawson's Classroom Test of Scientific Reasoning and Foil test.

Our results show that little knowledge transfer from the learning activity to the prism foil problem occurred. It seems that students in the prediction group benefited the most from the instructional method, while transfer was poorer in the lab group and was not observed in the traditional group. We recognized the distance of transfer, the low effect of learning methods and single-step problem solving strategy as possible reasons that little transfer occurred. Additionally, we found that asking for prediction during demonstration experiments may help non-formal thinkers to transfer knowledge. However, inquiry-based laboratory explorations without explicit reflection on previously acquired knowledge may not be enough for successful knowledge transfer.

\section{Acknowledgements}

The authors are thankful for the kind cooperation of the following highschool teachers: Ruben Belina, Marjana Benedik, Rok Capuder, Timotej Maroševič, and Florjana Žigon.

\section{References}

Alfieri, L., Brooks, P. J., Aldrich, N. J., \& Tenenbaum, H. R. (2011). Does Discovery-Based Instruction Enhance Learning? Journal of Educational Psychology, 103(1), 1-18.

Ates, S., \& Catalogu, E. (2007). The Effects of Students' Reasoning Abilities on Conceptual Understandings and Problem-Solving Skills in Introductory Mechanics. European Journal of Physics, 28(6), 1161-1171. 
Atkin, J. M., \& Karplus, R. (1962). Discovery or invention? The Science Teacher, 29(5), 45-47.

Barnett, S. M., \& Ceci, S. J. (2002). When and where do we apply what we learn? A taxonomy for far transfer. Psychological Bulletin, 128(4), 612-637.

Bransford, J. D., Brown, A. L., Cocking, R. R., Donovan, M. S., Bransford, J. D., \& James, W. P.

(Eds.) (200o). How People Learn: Brain, Mind, Experience, and School. Washington, D. C.: National Academy Press.

Bybee, R. W., Taylor, J. A., Garden, A., Van Scotter, P., Powell, J. C., Westbrook, A., \& Landes, N. (2006). The BSCS 5 E Instructional Model: Origins and Effectiveness, Colorado Springs: BSCS. Catrambone, R. (1998). The Subgoal Learning Model: Creating Better Examples So That Students Can Solve Novel Problems. Journal of Experimental Psychology: General, 127(4), 355-376.

Coletta, V. P., \& Phillips, J. A. (2005). Interpreting FCI Scores: Normalized Gain, Pre-instruction Scores, and Scientific Reasoning Ability. American Journal of Physics, 73(12), 1172-1182.

Crouch, C. H., Fagen, A. P., Callan, J. P., \& Mazur, E. (2004). Classroom Demonstrations: Learning Tools or Entertainment? American Journal of Physics, 72(6), 835-838.

Duschl, R. A., Schweingruber, H. A., \& Shouse, A. W. (2007). Taking science to school: Learning and teaching science in grades K-8. Washington, DC: National Academies Press.

Eraut, M. (2004). Transfer of Knowledge between Education and Workplace Settings. In H. Rainbird, A. Fuller, \& H. Munro (Eds.), Workplace Learning in Context (pp. 201-221). London: Routledge. Etkina, E., \& Heuvelen, A. V. (2001). Investigative Science Learning Environment: Using the Processes of Science and Cognitive Strategies to Learn Physics. In S. V. Franklin \& K. Cummings (Eds.), Proceedings of the 2001 Physics Education Research Conference (pp. 17-21). Rochester, New York.

Gick, M. L. (1986). Problem-Solving Strategies. Educational Psychologist, 21(1-2), 99-120.

Gojkošek, M., Planinšič, G., \& Sliško, J. (2012). Students' Construction of the Explanatory Models for the Prismatic Foil: Influence of Cognitive Level and Task Sequencing. In A. Lindell, A.-L. Kähkönen, \& J. Viiri (Eds.), Physics Alive. Proceedings of the GIREP-EPEC 2011 Conference, (pp. 37-42). Jyväskylä: University of Jyväskylä.

Karplus, R. (1977). Science Teaching and the Development of Reasoning. Journal of Research in Science Teaching, 14(2), 169-175.

Lawson, A. E. (1978). The Development and Validation of a Classroom Test of Formal Reasoning. Journal of Research in Science Teaching, 15(1), 11-24.

Lawson, A. E., Alkhoury, S., Benford, R., Clark, B. R., \& Falconer, K. A. (200o). What Kinds of Scientific Concepts Exist? Concept Construction and Intellectual Development in College Biology. Journal of Research in Science Teaching, 37(9), 996-1018.

Marini, A., \& Genereux, R. (1995). The Challenge of Teaching for Transfer. In A. McKeough, J. L. Lupart, \& A. Marini (Eds.), Teaching for Transfer: Fostering Generalization in Learning (pp. 1-19). Mahwah, N.J.: Lawrence Erlbaum.

Marušić, M., \& Sliško, J. (2012). Influence of Three Different Methods of Teaching Physics on the Gain in Students' Development of Reasoning. International Journal of Science Education, 34(2), 
301-326.

Mayer, R. E. (2004). Should There Be a Three-Strikes Rule Against Pure Discovery Learning? The Case for Guided Methods of Instruction. American Psychologist, 59(1), 14-19.

McDermott, L. C. (1991). Millikan Lecture 1990: What We Teach and What is Learned - Closing the Gap. American Journal of Physics, 59(4), 301-315.

McNeill, K. L., Lizotte, D. J., Krajcik, J., \& Marx, R. W. (2006). Supporting students' construction of scientific explanations by fading scaffolds in instructional materials. Journal of the Learning Sciences, 15(2), 153-191.

Meltzer, D. E., \& Thornton, R. K. (2012). Resource Letter ALIP-1: Active-Learning Instruction in Physics. American Journal of Physics, 8o(6), 478-496.

Michael, J. A., \& Modell, H. I. (2003). Active Learning in Secondary and College Science Classrooms: A Working Model for Helping the Learner to Learn. Mahwah, N.J.: Lawrence Erlbaum.

Planinšič, G., \& Gojkošek, M. (2011). Prism foil from an LCD monitor as a tool for teaching introductory optics. European Journal of Physics, 32(2), 601-613.

Redfors, A., \& Ryder, J. (2001). University Physics Students' Use of Models in Explanations of Phenomena Involving Interaction between Metals and Radiation. International Journal of Science Education, 23(12), 1283-1301.

Ruiz-Primo, M. A., Li, M., Tsai, S. P., \& Schneider, J. (2010). Testing One Premise of Scientific Inquiry in Science Classrooms: Examining Students' Scientific Explanations and Student Learning. Journal of Research in Science Teaching, 47(5), 583-608.

She, H.-C., \& Lee, C.-Q. (2008). SCCR Digital Learning System for Scientific Conceptual Change and Scientific Reasoning. Computers \& Education, 51(2), 724-742.

White, R., \& Gunstone, R. (1992). Probing Understanding. London: Falmer Press.

\section{Biographical note}

Mihael Gojkošek is a $\mathrm{PhD}$ student of physics education at the Faculty of mathematics and physics, University of Ljubljana, Slovenia. His research addresses students' ability to construct explanations and predictions for interaction between light beam and prism foil. For last three years he has been a teaching assistant for courses Didactics of physics and Project work at the Faculty of Mathematics and Physics. He also participates in preparation of new textbooks for physics in elementary school.

Gorazd Planinšič is a professor of physics at Faculty of mathematics and physics, University of Ljubljana, Slovenia. He is leading undergraduate and post-graduate Physics Education program. He is also leading the Continuing education program for in-service secondary school physics teachers in Slovenia. His main interest is in development and didactical use of experiments. He 
is chair of Physics Education Division at European Physical Society and co-founder and collaborator of Slovenian hands-on science centre The House of Experiments.

JosıP SLIško (BSc in physics, MSc in philosophy of physics, $\mathrm{PhD}$ in philosophical sciences) teaches courses on physics and mathematics education at Facultad de Ciencias Físico Matemáticas of the Benemérita Universidad Autónoma de Puebla. His research interests include students' explanatory and predictive models of physical phenomena, students' strategies for solving untraditional physics and mathematics problems, presentation of knowledge in textbooks and the design of active learning sequences that promote cognitive, metacognitive and emotional development of students. Josip Sliško is the author or co-author of 80 journal articles and 12 physics textbooks. Since 1993, every last week in May, he is the president of the committee that organizes an international workshop called New Trends in Physics Teaching. 